\title{
Suitability and Carrying Capacity of Seagrass for Snorkeling on Tunda Island, Banten
}

\author{
Prafitri Saraswati Darmawan ${ }^{1 *}$, Wahyuniar Pamungkas ${ }^{2}$, Indah Riyantini $^{2}$, Sri Astuty ${ }^{2}$ \\ ${ }^{1}$ Faculty of Fisheries and Marine Sciences, University of Padjadjaran, Sumedang, Indonesia \\ ${ }^{2}$ Departement of Marine Sciences, Faculty of Fisheries and Marine Sciences, University of Padjadjaran, Sumedang, \\ Indonesia
}

\section{Abstract}

The seagrass ecosystem has ecological and economical functions, which can provide benefits to the surrounding community as a conservation area and marine tourism. Studies on the suitability of seagrass ecosystems for marine tourism, especially snorkeling, on Tunda island are needed to support their use. The purpose of this research is to evaluate the suitability and carrying capacity of seagrass ecosystems on Tunda Island, Banten for marine tourism snorkeling. The research was conducted in March - July 2019. The research method carried out was a survey with five observation stations in the seagrass area on Tunda Island. The parameters observed are seagrass cover, seagrass type, fish type, brightness, temperature, depth, current speed, substrate type, salinity, $\mathrm{pH}, \mathrm{DO}$, facilities, and infrastructure as well as accessibility. Data analysis was performed in a comparative description between five observation stations. The result of this research showed that station 1 (in north area) and station 4 (in southeast region) had a value of the Tourism Suitability Index in the range of $73.15 \%-77.78 \%$ and included in the Suitable category, which are potential stations to be developed as snorkeling marine tourism areas. The carrying capacity of the seagrass area for snorkeling tours on Tunda Island, Banten with an area of 11,197 hectares is 44 people per day.

Keywords: Marine tourism, regional carrying capacity, regional suitability, seagrass, snorkeling.

\section{INTRODUCTION}

Ecotourism in Indonesia has been studied extensively because of its economic benefits and contributions to local development. In this case, tourism to natural environments, especially coastal and beach areas in small islands. It happened to be more famous because the coastal and beach area are the potential to be developed on its biodiversity, tourism, and sustainability value $[1,2]$.

Tunda Island is a small island in Serang Regency. Tunda Island has a coastal ecosystem consists of mangrove, seagrass, and coral reef ecosystems, which were still natural. Seagrass ecosystem is a place to live and breed for various marine biotas, such as sea turtle, dugongs, fish, echinoderms, and invertebrate biota. It makes seagrass beds have functioned as a nursery ground, feeding ground, and spawning ground. Besides being beneficial from the ecological view, seagrasses can also be used as educational objects and conservation-based recreation objects [3].

Seagrass conditions on Tunda Island included in the fine category, with its cover reaching $66 \%$ [4]. Seagrass species that scattered in Tunda

\footnotetext{
"Correspondence address:

Prafitri Saraswati Darmawan

E-mail : psaraswatid@gmail.com

Address : Jl. Raya Bandung Sumedang KM 21, Jatinangor, West Java, 45363.s
}

Island waters are Cymodocea rotundata, $C$. serullata, Enhalus acoroides, Halophila ovalis, and Thalassia hemprichii [5]. Fine seagrass conditions and the many associated biotas in the seagrass beds make the seagrass ecosystem on Tunda Island interesting to be developed as a marine tourism object.

Marine tourism is a tourism activity that prioritizes underwater resources and seawater dynamics, such as diving, snorkeling, swimming, boating, sunbathing, water sports, seagrass tours, etc [6]. Snorkeling tourism is also one of the marine tourism activities that can be done in the seagrass ecosystem. Along with the tourism activities that could be done, it may also cause the degradation of the seagrass ecosystem. This marine tourism activity can be one of the sectors of development and sustainable development, and can provide income for the community without losing the conservation value of the seagrass ecosystem [7]. This research was aimed to evaluate the suitability and carrying capacity of seagrass ecosystems on Tunda Island, Banten for marine tourism snorkeling.

\section{MATERIAL AND METHOD}

The research was conducted in March-July 2019, which consisted of several stages, namely the survey phase, the data collection stage, and data processing. The research location is in the waters of Tunda Island, Banten, which is one of 
the tourist destination locations. There are five data collection stations located in certain parts of Tunda Island waters. The selection of each data sampling location based on the differentiation of seagrass and its habitat characteristics [8]. The coordinates stated in Figure 1.

\section{Seagrass Vegetation}

Data on seagrass vegetation taken includes the seagrass cover percentage and its species. Quadrant transect method is a method used to obtain the cover percentage and seagrass species using quadrant transects measuring $50 \times 50 \mathrm{~cm}^{2}$ with four small boxes in quadrant transects (Fig. 2). There are three transect lines in each station
[9]. The length of the transect line is $100 \mathrm{~m}$, with the distance from one transect line to another is $50 \mathrm{~m}$ so that the total area is $100 \times 100 \mathrm{~m}^{2}$. The distance between one quadrant and another quadrant transect is $10 \mathrm{~m}$ so that the total quadrant transect of each transect line is 11 . The starting point of the transect placed at a distance of 5-10 $\mathrm{m}$ from the shore, located where the seagrass is encountered.

The results of the data taken in the field will be processed in the form of a percentage of seagrass cover. The value of the average seagrass coverage per location is categorized into four percentage categories (\%), as seen in Table 1.

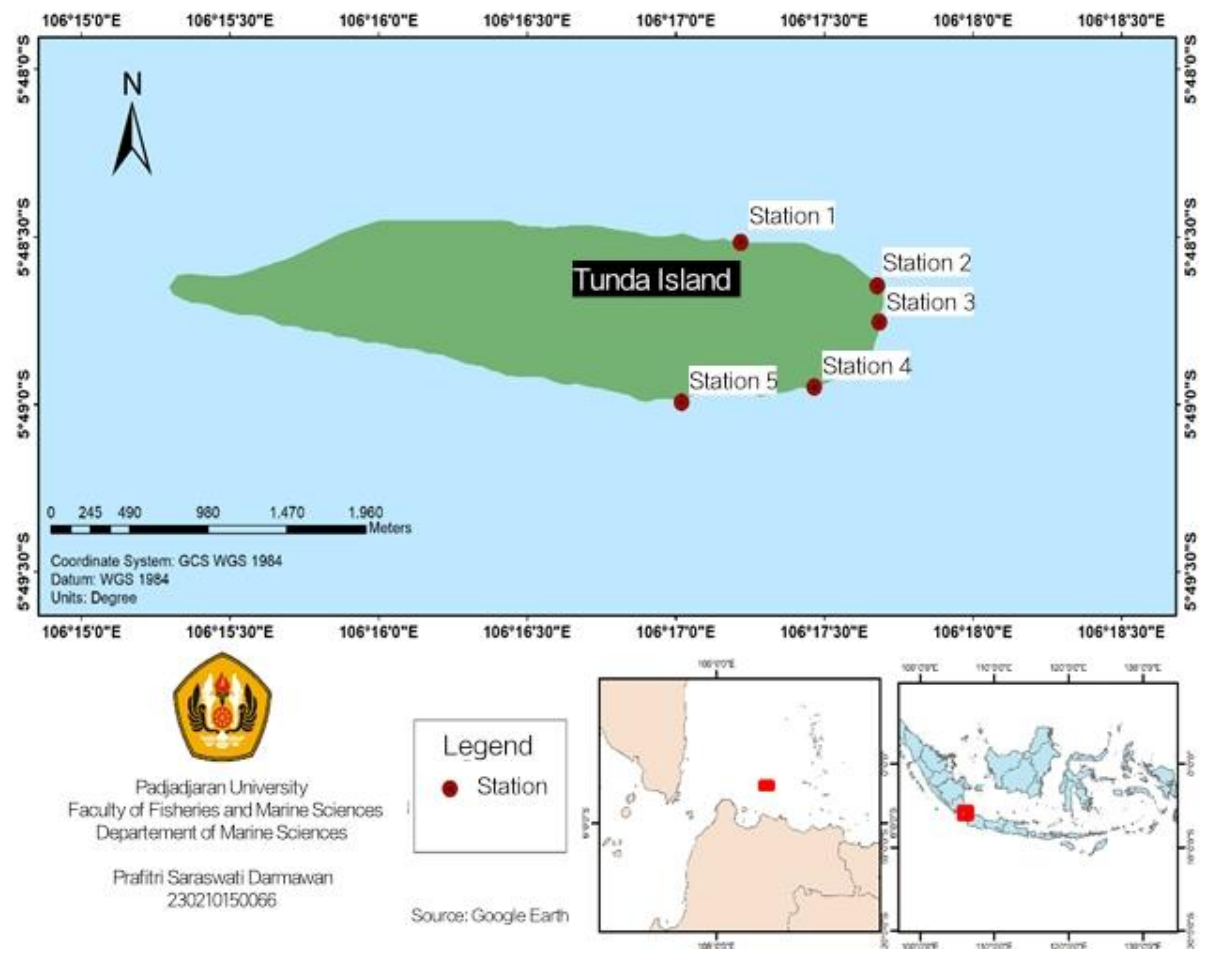

Figure 1. Research Location
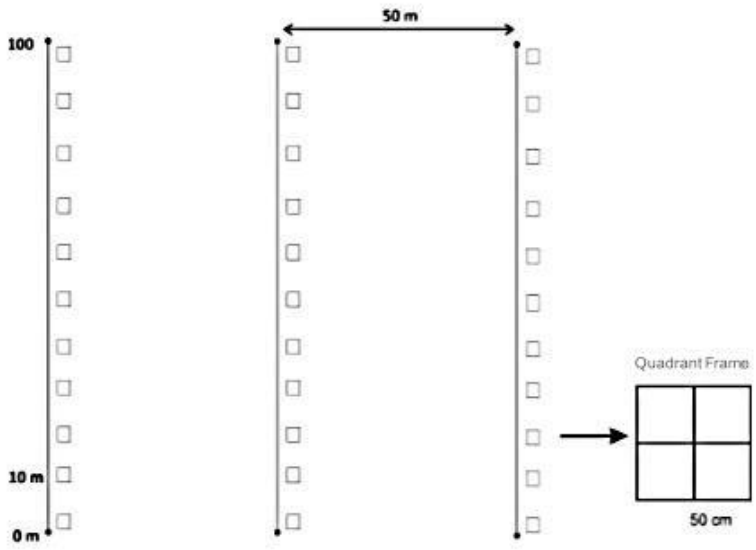

Coastal

Figure 2. Quadrant transect 
Average Seagrass Cover(\%) $=$

Area of seagrass cover throughout transects

Area of the entire transect quadrant

Table 1. Categories of Seagrass Cover Area [9]

\begin{tabular}{cc}
\hline Coverage (\%) & Category \\
\hline $0-25$ & Rarely \\
$26-50$ & Moderate \\
$51-75$ & Dense \\
$76-100$ & Very Dense \\
\hline
\end{tabular}

\section{Biota Association}

Identification of association biota is done by observing the biota that lives around the seagrass ecosystem using visual methods, by snorkeling in the area around the seagrass ecosystem. The observed biota divided into coral fish and other invertebrates, and the identification stated as the family name of each biota. The identification of the biota is needed as the parameter of the water quality and seagrass ecosystem richness [8].

\section{Waters Quality}

Water quality is including physical-chemical parameters. There are eight parameters, namely substrate type which determined by visual observation, visibility and depth are determined by using Secchi disk, current speed determined by tracking float tools, temperature determined by a thermometer, salinity determined by the help of refractometer, also $\mathrm{DO}$ and $\mathrm{pH}$ determined by the help of DO meter and $\mathrm{pH}$ meter [8]. The results of the data taken are then compared with the quality standards stated in the Indonesia's Minister of Environment Decree No. 51 of 2004.

\section{Tourism Suitability Index (TSI)}

The tourism suitability analysis is using a suitability matrix based on the importance of each parameter to support activities in the area. The suitability matrix of the seagrass area for the snorkelling tourism category showed in Table 2 . The formula used to determine the suitability of seagrass tourism is the TSI formula or the
Tourism Suitability Index, while the calculation method [10].

Description:

$$
\mathrm{TSI}=\Sigma\left(\frac{\mathrm{Ni}}{\mathrm{N} \max }\right) \times 100 \%
$$

$$
\begin{array}{ll}
\mathrm{TSI} & =\text { Tourism Suitability Index } \\
\mathrm{Ni} & =\text { Parameter value (Weight } \mathrm{x} \text { Score) } \\
\mathrm{N} \max & =\text { Maximum value of a tourism category }
\end{array}
$$

\section{Regional Carrying Capacity (RCC)}

RCC is the maximum number of visitors who can be physically accommodated in the area, provided at a certain time without causing disturbance to nature and humans. The completeness of the data in using the RCC formula will be completed by the visitor's ecological matrix and the visitor activity matrix.

It is stated that the ecological potential $(\mathrm{K})$ of snorkeling activity is one visitor per $100 \times 5 \mathrm{~m}$ unit area, while the time provided by the region for tourism activities in one day (Wt) is six hours, and the time spent by visitors for snorkeling activity $(\mathrm{Wp})$ is three hours. Based on the explanation above, the calculation of the Regional Carrying Capacity is as follows:

$$
\begin{aligned}
& R R C=K x(L p / L t) x(W t / W p) \\
& \text { Description: } \\
& \mathrm{RRC} \quad=\text { Regional Carrying Capacity } \\
& \mathrm{K}=\text { = ecological potential } \\
& \text { Lp =Area or length of area that can be utilized } \\
& \text { Lt = Unit area for tourism certain categories } \\
& \text { Wt }=\text { Tourism activities in one day } \\
& \mathrm{Wp} \quad=\text { Time spent by visitors for snorkeling activity }
\end{aligned}
$$

In accordance with Indonesia's Government Rules No. 18/1994 concerning the Exploitation of

\begin{tabular}{|c|c|c|c|c|c|c|c|c|c|c|}
\hline No. & Parameter & Score & CategoryS1 & Score & Category S2 & Score & Category S3 & Score & Category $\mathbf{N}$ & Score \\
\hline 1. & Seagrass Cover (\%) & 5 & $>75$ & 4 & $>50-75$ & 3 & $25-50$ & 2 & $<25$ & 1 \\
\hline 2. & Visibility (\%) & 5 & $>75$ & 4 & $>50-75$ & 3 & $25-50$ & 2 & $<25$ & 1 \\
\hline & Fish Species (Family) & 5 & $>10$ & 4 & $6-10$ & 3 & $3-5$ & 2 & $<3$ & 1 \\
\hline & Seagrass Species & 5 & $\geq 4$ species & 4 & 3 species & 3 & 2 species & 2 & 1 species & 1 \\
\hline & Substrate Type & 3 & Coral sand & 4 & Sand & 3 & Muddy Sand & 2 & Muddy & 1 \\
\hline & Current Speed $\left(\mathrm{cm} . \mathrm{s}^{-1}\right)$ & 2 & $0-15$ & 4 & $>15-30$ & 3 & $>30-50$ & 2 & $>50$ & 1 \\
\hline
\end{tabular}
Nature Tourism in the Utilization Zone of National Parks and Natural Tourism Parks, the area permitted to be developed is $10 \%$ of the area of utilization zone. So the calculation of the Regional Capability of Utilization (RCU) is done by the formula:

Description:

$$
\mathrm{RCU}=10 \% \times \mathrm{RRC}
$$

RRC= Regional Carrying Capacity

RCU = Regional Capability of Utilization

Table 2. Suitability Matrix of Seagrass Areas for Snorkeling Tourism [9]

Notes: Maximum score are 108, S1 (VerySuitable) with a value of $81 \%-100 \%$, S2(Suitable) with a value of $61 \%-<80 \%$, S3 (Conditionally Suitable) with a value of $41 \%-<60 \%$, N (Not Suitable) with a value $<40 \%$. 


\section{RESULTS AND DISCUSSION \\ Water Quality}

Water quality assessed from the results of measurements of several physical and chemical parameters, which play roles in supporting the life of seagrass biota, as also stated in Indonesia's Indonesia's Minister of Environment Decree No. 51 of 2004 about Sea Water Quality Standards for Marine Biota. The results of data retrieval can be seen in Table 3.

The results of data collection in the field showed that there are three types of substrates that have been identified, namely coral-sand, sand, and muddy sand. The different types of substrates will affect the type of seagrass that grows on it. Seagrasses tend to live on sandy, muddy substrates, or on table fragments [11] Substrates play a role in the stability of seagrasses, which are growing media, and nutrient source cycles [12].

The visibility value is related to the depth of the water. The depth obtained is ranging from $0.4 \mathrm{~m}-1 \mathrm{~m}$, with visibility reaching $100 \%$. Water visibility is strongly influenced by weather conditions, measurement time, turbidity, and suspended solids [13]. High water visibility affects the visibility of tourists on existing attractions. With a shallow depth, sunlight penetration is expected to enter the bottom, and there are no factors that can block incoming the light, such as mud, fine sand, or other organic or inorganic materials [14].

The speed of water currents is influenced by the wind that moves on the surface of the water. In addition to the wind that forms currents, the topography forms the seabed and surrounding islands can form currents [15]. When collecting current data at five observation stations, the obtained velocity ranges from 2 to $6.12 \mathrm{~cm} . \mathrm{s}^{-1}$. The current velocity values obtained are classified as very slow [16]. Currents with very slow speeds have values $<10 \mathrm{~cm}$ and are able to support the life of seagrass ecosystems.
The measured water temperature is indicated to be able to support the life in it properly. Enhalus acoroides is able to live at temperatures of $26.5-32.5^{\circ} \mathrm{C}$, and in shallow waters can tolerate temperatures up to $38^{\circ} \mathrm{C}$ until the conditions recede [17]. If the temperature reaches $45^{\circ} \mathrm{C}$, then the growth of seagrass will be disrupted, and seagrass will experience stress until it can experience death [18]. Salinity measured worth 21.5-29 ppt. Seagrass vegetation has a fairly high tolerance to salinity, which is $10-40$ ppt with its optimum at $35 \mathrm{ppt}$. Decreased salinity will reduce the ability of seagrass photosynthesis. The low salinity value compared to this quality standard can be caused by patterns of water circulation, evaporation, precipitation, rainfall, and freshwater supply [19].

DO data in waters can be said to be fair. It shows that oxygen demand both for chemical and biological processes of biota in the waters of Tunda Island are equals. Or in other words, seen from the DO value, the waters of Tunda Island are sufficient to support life contained in the seagrass ecosystem.

Water $\mathrm{pH}$ ranges from $7-8.5$ and can support the life of biota that lives in its waters. The $\mathrm{pH}$ value can be influenced by biological, chemical activities such as photosynthesis, temperature, DO, and pollutants that enter the waters. Biota death is more often caused by low $\mathrm{pH}$ than high $\mathrm{pH}[20]$.

\section{Seagrass Vegetation Condition}

The results of observations of seagrass vegetation at the research site on Tunda Island, based onfive observation stations. There were five types of seagrasses, namely Cymodocea rotundata (Cr), Cymodocea serrulata (Cs), Enhalus acoroides (Ea), Halophila ovalis ( $\mathrm{Ho}$ ) and Thalassia hempricii (Th) with varying mean of seagrass cover at each station, obtained from three lines transects (Table 4).

Table 3. Water Quality Data

\begin{tabular}{|c|c|c|c|c|c|c|c|c|}
\hline \multirow[b]{2}{*}{ Station } & \multicolumn{8}{|c|}{ Parameters } \\
\hline & Substrate Type & $\begin{array}{c}\text { Visibility } \\
(\%)\end{array}$ & $\begin{array}{c}\text { Depth } \\
\text { (m) }\end{array}$ & $\begin{array}{l}\text { Current Speed } \\
\left(\mathrm{cm} . \mathrm{s}^{-1}\right)\end{array}$ & $\begin{array}{c}\text { Temperature } \\
\left({ }^{\circ} \mathrm{C}\right)\end{array}$ & $\begin{array}{c}\text { Salinity } \\
\text { (ppt) }\end{array}$ & $\begin{array}{c}D O \\
\left(\mathrm{~m} \cdot \mathrm{L}^{-1}\right)\end{array}$ & $\mathrm{pH}$ \\
\hline 1 & Coral Sand & 100 & 0,4 & 3 & 32 & 28,8 & 9,65 & 8,1 \\
\hline 2 & Coral Sand & 100 & 0,4 & 2 & 31 & 28,7 & 8 & 7,8 \\
\hline 3 & Coral Sand & 100 & 0,5 & 2 & 29,5 & 26 & 8,3 & 7,5 \\
\hline 4 & Sand & 100 & 0,55 & 2,78 & 34 & 21,5 & 7,86 & 8,2 \\
\hline 5 & Muddy Sand & 100 & 1 & 6,12 & 29,7 & 29 & 8,25 & 7,7 \\
\hline \multicolumn{2}{|c|}{ Quality Standard } & \multicolumn{2}{|c|}{$>3$} & - & $28-30$ & $33-34$ & $>5$ & $7-8,5$ \\
\hline
\end{tabular}


Table 4. Average Seagrass Cover at Research Locations

\begin{tabular}{cccccccc}
\hline \multirow{2}{*}{ Station } & \multicolumn{9}{c}{ Seagrass Cover per-Species (\%) } \\
\cline { 2 - 7 } & rotundata & $\begin{array}{c}\text { Cymodocea } \\
\text { serrulata }\end{array}$ & $\begin{array}{c}\text { Enhalus } \\
\text { acoroides }\end{array}$ & $\begin{array}{c}\text { Halophila } \\
\text { ovalis }\end{array}$ & $\begin{array}{c}\text { Thalassia } \\
\text { hempricii }\end{array}$ & $\begin{array}{c}\text { Average per- } \\
\text { Station }\end{array}$ \\
\hline 1. & 28.75 & 3.71 & 0 & 0 & 0,3 & 33.94 \\
2. & 0.53 & 1.02 & 0.64 & 0.3 & 4.43 & 6.93 \\
3. & 1.25 & 2.19 & 2.5 & 0 & 4.2 & 10.6 \\
4. & 0.34 & 2.05 & 12.69 & 1.55 & 5.46 & 22.08 \\
5. & 0 & 0 & 31.02 & 0 & 5.0 & 34.85 \\
\hline
\end{tabular}

The diversity of species that grow in the area is influenced by the type of substrate. The horizontal distribution of seagrasses influenced by substrate characteristics and water motion conditions [19]. The diversity of species found in the field shows that the quality of these waters is in fine condition and is not contaminated with harmful elements. The diversity that grows in the area is also influenced by the quality of the waters. Seagrass coverage is a percentage value of the seagrass ecosystem cover that describes how wide the seagrass covers a water area. The percentage value of seagrass coverage does not always equal to the percentage value of seagrass species in an area because the percentage of coverage are considering the leaf scope while the density of species seen by the number of stands.

\section{Biota Association}

Identification of associated biota in seagrass areas in the research location, separated into two groups, namely coral fish and other biotas. Observations were made visually at five observation stations. The results of coral fish observations are listed in Table 5.

Table 5. Associated Coral Fish in the Seagrass Area, Tunda Island

\begin{tabular}{cl}
\hline Station & \multicolumn{1}{c}{ Coral Fish (Family) } \\
\hline 1. & Nemipteridae, Apogonidae, Labridae \\
2. & Nemipteridae, Apogonidae, Labridae, \\
3. & Nemipteridae, Apogonidae, Labridae \\
4. & Nemipteridae, Apogonidae, Labridae, \\
5. & Pomacentridae \\
\hline
\end{tabular}

Observation of coral fish at the research location, obtained as many as four families, namely Nemipteridae, Apogonidae, Labridae, and Pomacentridae (Table 5). The four families were only found at station 4, while at the other station, only three families were found scattered in various ways. Coral fish from the Pomacentridae family show a preference attitude that is limited to the substrate and depth and is known as fish that are territorial, social, spatial, and relatively stable. Pomacentridae family belongs to the major group, as well as the family
Apogonidae and Labridae. Pomacentridae family has a variety of diverse colors. The Nemipteridae family belongs to the target fish group, a carnivorous fish that eats small bottom fish, cuttlefish, crustaceans, or worms. Coral fish families found the majority are fish families that spawn and migrate temporarily in the seagrass ecosystem, to then return to their habitat, the coral reef ecosystem. The observations of other associated biotas in the seagrass area of Tunda Island are listed in Table 6.

Table 6. Other Biota Associating in the Seagrass Area, Tunda Island

\begin{tabular}{|c|c|}
\hline Station & Biota Association \\
\hline 1. & $\begin{array}{l}\text { Sea cucumbers (family Holothuroidae), snails } \\
\text { (class Gastropods) }\end{array}$ \\
\hline 2. & $\begin{array}{l}\text { Sea cucumbers (family Holothuroidae), snails } \\
\text { (class Gastropods), crustaceans and crabs } \\
\text { (subfilum crustaceans) }\end{array}$ \\
\hline 3. & $\begin{array}{l}\text { Sea cucumbers (family Holothuroidae), snails } \\
\text { (class Gastropods), crustaceans and crabs } \\
\text { (subfilum crustaceans) }\end{array}$ \\
\hline 4. & $\begin{array}{l}\text { Sea cucumbers (family Holothuroidae), snails } \\
\text { (class Gastropods), crustaceans and crabs } \\
\text { (subfilum crustaceans), sea urchins (family } \\
\text { Echinoidae), starfish (family Oreastridae) }\end{array}$ \\
\hline 5. & Snails (Gastropods class) \\
\hline
\end{tabular}

Associated biotas other than coral fish found at the data collection station are sea cucumber, snails, crustaceans, crabs, sea urchins, and starfish are invertebrate biota that often found in seagrass ecosystems. Station 4 identified to have the highest diversity of biota associations compared to the other four stations. Itis presumably because station 4 has the most diverse type of seagrass with a moderate percentage of cover. This diversity supported by the type of sand substrate, which is indeed covered by various types of seagrass. The coralsand substrate and sand are a type of substrate that has a high enough oxygen content to allow many biotas to live on the substrate. A sand substrate is also a habitat for these invertebrate biotas.

The shallow water depth also affects the penetration of light entering the water, supporting seagrass as a photosynthetic agent. In 
addition, the condition of the seagrass ecosystem is directly adjacent to the coral ecosystem, thus enriching the biota that can live in it. The velocity of the calm waters also supports the life of the associated biota. The relatively quiet current velocity favored by small fish and invertebrates such as bivalves, gastropods, crustaceans, and others [19]. It shows that the seagrass ecosystem in Tunda Island is still in fine condition and productive to be able to support the lives of various marine biota and add attraction to be used as marine tourism activities, especially snorkeling.

\section{Suitability of Seagrass Areas for Snorkeling Tourism}

The suitability index of the seagrass area for snorkeling tours assessed through seven parameters, namely seagrass cover, visibility, associated biota, seagrass species, substrate type, current speed, and depth [9]. The determination of suitability is based on the multiplication of scores and weights obtained from each parameter. The suitability of the area can be seen from the level of suitability percentage obtained by summing the values of all parameters, while the results obtained are listed in Table 7.

Based on the calculation of the suitability of the seagrass area for snorkeling tours for stations 1 to station 5, the value of TSI on Tunda Island, Banten, ranged from 59.26 - 77.78\%. The station 1 , station 2, station 3 and station 4 are included in the category S2 or Suitable, and station 5 is included in the category S3 or Conditionally Suitable (Table 7). In general, it can be said that the seagrass area in the waters of Tunda Island, Banten, is suitable to be used as a marine tourism area for snorkeling, but there needs to be supervision and maintenance of the seagrass ecosystem and the surrounding area. While the S3 category can be interpreted that the seagrass area at this station, is inadequate to be used as a tourist area because the seagrass species are few, as there are only two seagrass types, although the seagrass cover is quite large relative to station 1. Also, some factors can become obstacles for snorkeling tours, including water that is somewhat turbid due to the type of muddy sand substrate, as well as the location of seagrasses close to residential areas with their activities.

The similarity of the categories found in each station does not guarantee that the value of each parameter owned by each station is the same. The size of the value obtained is adjusted to the weight of the calculated value. Some parameters with high weights show significant differences from each station, such as seagrass cover, brightness, seagrass species, and associated fish species. The identified TSI value can be used as a recommendation whether or not, the seagrass area in Tunda Island is to be used as a snorkeling tourism area by considering the ecological conditions of the existing seagrass resources. The map of the suitability value of the seagrass area for snorkeling tours can be seen in Figure 3.

\section{Carrying Capacity of Seagrass for Snorkeling Tourism}

The carrying capacity of the seagrass area for snorkeling tours obtained in this research, calculated by the RRC formula was 448 people per day with $500 \mathrm{~m}^{2}$ per person because the area of the seagrass area on Tunda Island was 11,197 hectares. This carrying capacity is the carrying capacity of the entire existing seagrass area and cannot necessarily be realized.

Table 7. Level of Suitability of Seagrass Areas for Snorkeling Tourism on Tunda Island, Banten

\begin{tabular}{|c|c|c|c|c|c|c|c|c|c|c|}
\hline \multirow[t]{2}{*}{ Parameter } & \multicolumn{2}{|c|}{ Station 1} & \multicolumn{2}{|r|}{ Station 2} & \multicolumn{3}{|c|}{ Station 3} & \multirow{2}{*}{$\begin{array}{c}\text { Station } 4 \\
\text { Scores }\end{array}$} & \multicolumn{2}{|c|}{ Station 5} \\
\hline & Result & Scores & Result & Scores & Result & Scores & Result & & Result & Scores \\
\hline Seagrass Coverage (\%) & 33.94 & 10 & 6.93 & 5 & 10.6 & 5 & 22.08 & 10 & 34.85 & 10 \\
\hline Visibility (\%) & 100 & 20 & 100 & 20 & 100 & 20 & 100 & 20 & 100 & 20 \\
\hline Coral Fish (Family) & 5 & 10 & 6 & 15 & 6 & 15 & 9 & 15 & 4 & 10 \\
\hline Seagrass Species & 3 & 15 & 5 & 20 & 5 & 20 & 5 & 20 & 2 & 10 \\
\hline Substrate Type & C-S & 12 & C-S & 12 & C-S & 12 & S & 9 & M-S & 6 \\
\hline CurrentSpeed $\left(\mathrm{cm} \cdot \mathrm{s}^{-1}\right)$ & 3 & 8 & 2 & 8 & 2 & 8 & 2.78 & 6 & 6.12 & 2 \\
\hline $\operatorname{Depth}(\mathrm{m})$ & 0.4 & 4 & 0.4 & 4 & 0.5 & 4 & 0.55 & 4 & 1 & 4 \\
\hline $\begin{array}{l}\text { TSI } \\
\text { (\%) }\end{array}$ & \multicolumn{2}{|c|}{73.15} & \multicolumn{2}{|c|}{77.78} & \multicolumn{2}{|c|}{77.78} & \multicolumn{2}{|c|}{77.78} & \multicolumn{2}{|c|}{59.26} \\
\hline Category & \multicolumn{2}{|c|}{$\begin{array}{c}\text { S2 } \\
\text { (Suitable) }\end{array}$} & \multicolumn{2}{|c|}{$\begin{array}{c}\text { S2 } \\
\text { (Suitable) }\end{array}$} & \multicolumn{2}{|c|}{$\begin{array}{c}\text { S2 } \\
\text { (Suitable) }\end{array}$} & \multicolumn{2}{|c|}{$\begin{array}{c}\text { S2 } \\
\text { (Suitable) }\end{array}$} & \multicolumn{2}{|c|}{$\begin{array}{c}\text { S3 } \\
\text { (Conditionally } \\
\text { Suitable) }\end{array}$} \\
\hline
\end{tabular}

Notes: $\mathrm{CS}=$ Coral-Sand, $\mathrm{S}=$ Sand, $\mathrm{M}-\mathrm{S}=$ Muddy-Sand 

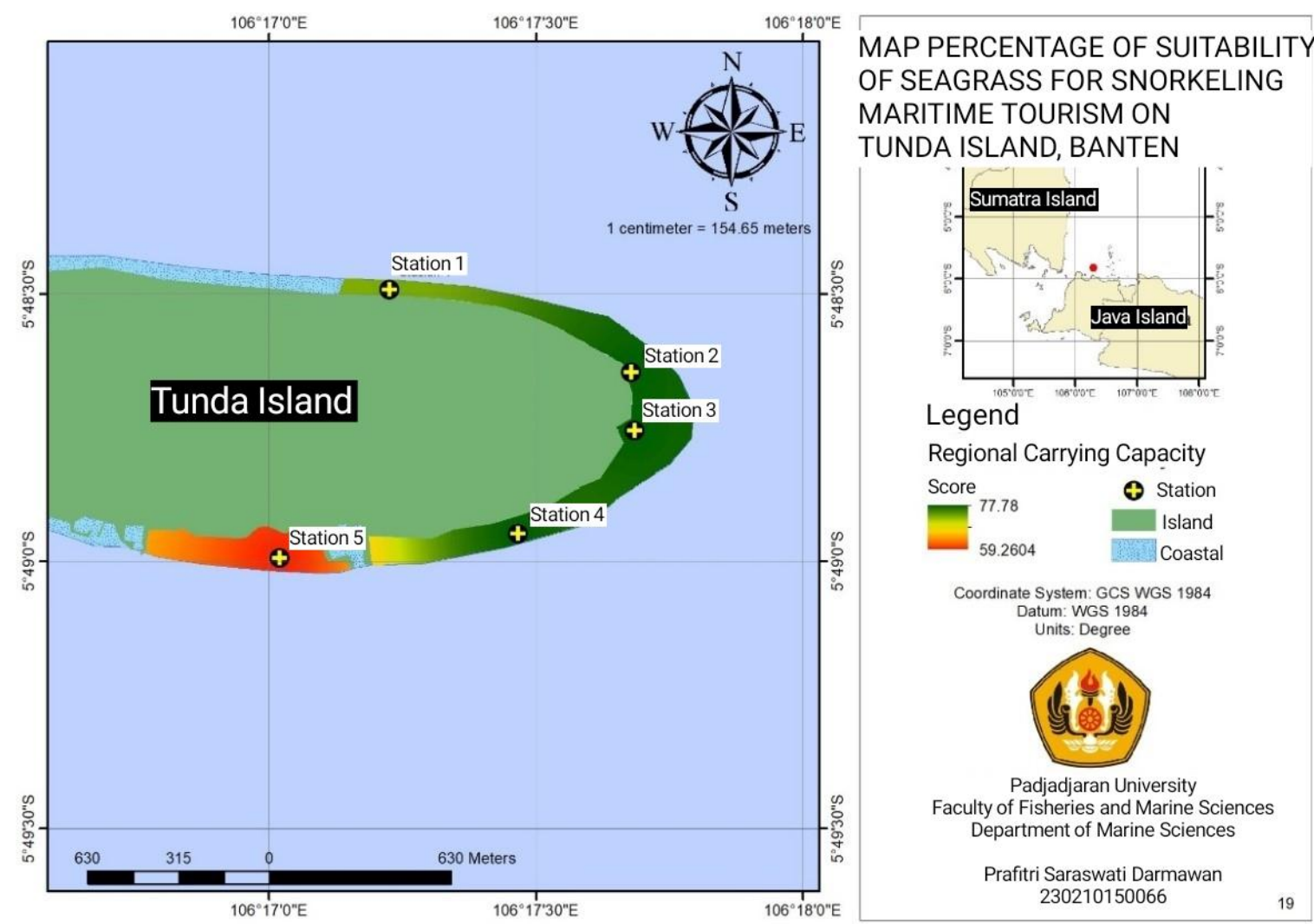

Figure 3.Suitability Map of Seagrass Area for SnorkelingTourismonTunda Island, Banten

In accordance with Indonesia Government Regulation No.18/1994 concerning Nature Tourism Exploitation in the Utilization Zone of National Parks and Natural Tourism Parks, the area permitted to be developed is $10 \%$ of the utilization zone area, so that the final value in the utilization of conservation tourism business activities[9]. The value of carrying capacity that can be used in seagrass areas for snorkeling tours on Tunda Island based on the RCU formula is 44 people per day. Tourists who come are expected not to exceed the carrying capacity, so that the seagrass area on the island of Tunda remains in fine condition and sustainable.

Based on the result of the research suggestions that can be made are the use of seagrass areas for snorkeling tourism is recommended to be carried out at station 1 (northern region) and station 4 (southeast region). Besides judging from the seagrass ecological conditions and their accessibility, but also need to accompanied by seagrass rehabilitation efforts to increase the extent of seagrass cover and diversity of seagrass species and seagrass association biota. Either way, for station 2 and station 3, rehabilitation needs to be done before it is utilized for snorkeling marine tourism. It is also necessary to calculate or study the carrying capacity of seagrass areas for snorkeling marine tourism specifically for each station, in order to evaluate the carrying capacity of the area to be more comprehensive.

\section{CONCLUSION}

Condition of seagrass area in the waters of Tunda Island is, there are five types of seagrasses, namely Cymodocea rotundata, Cymodocea serrulata, Enhalus acoroides, Halophila ovalis, and Thalassia hempricii. Percentage of seagrass cover between $6.93 \%$ $34.85 \%$. They are included in the category of rare-moderate, with water conditions classified as fine for seagrass growth and associated biota life.

Based on the suitability value of seagrass areas for snorkeling tourism on Tunda Island, in general seagrass areas in the north, east northeast and southeast regions of Tunda Island (TSI 73.15\% -77.58\%), while seagrass areas in the southern region are suitable conditional (TSI $59.26 \%)$. Carrying capacity of seagrass area in Tunda Island covering an area of 11,197 hectares for snorkeling tourism, as many as 44 people per day. 


\section{REFERENCES}

[1] Hakim, L., M.Soemarno, and S. K. Hong. 2012. Challenges for conserving biodiversity and developing sustainable island tourism in North Sulawesi Province, Indonesia. Journal of Ecology and Environment 35(2), 61-71.

[2] Hidayah, A., S. Sunarti, and L. Hakim. 2017. Potensi dan pengembangan objek wisata Bahari Tulamben, Kabupaten Karangasem, Bali. Jurnal Administrasi Bisnis 50(2), 93-98.

[3] Philips, C., and E. Menez. 1988. Seagrass. Press. Washington DC.

[4] Firdaus, A.M. 2013. Seagrass species association in the Tunda Island Waters of Banten Bay. Journal of Fisheries and Maritime Affairs 4(2).

[5] Azizah, N. N. 2016. Wide spatial analysis of seagrass cover in Tunda Serang Island, Banten. Bogor Agricultural Institute. Omniakuatika 12(1), 73-80.

[6] Darsoprajitno, S. 2013. Tourism ecology implementing object management and tourism attraction. PT. Angkasa. Bandung

[7] Mulyadi, A., D.Yoswaty, and I. Ilham. 2017. Environmental impact of the development of marine ecotourism in the Trikora Seagrass Conservation Area, Bintan, Riau Islands. Periodically Terubuk Fisheries 45(1), 96-111.

[8] Johan, Y. 2017. Study of seagrass potential in Basing Coast Limas, Sebangka Island, Senayang District, Lingga Regency. Master thesis. King Ali Hajj Maritime University.

[9] Malikusworo, H. and A. Nontji. 2014. Padang seagrass monitoring guide. PT. Sarana Komunikasi. Bogor.

[10] Yulianda, F. A., A. A. Fahrudin, S. Hutabarat, K. Harteti, S. H. Kang, and I. Adrianto. 2010. Integrated coastal and marine management. Forestry Training CenterMinistry of Forestry, SECEM-Korea International Cooperation Agency. Bogor.

[11] Newmaster, A. F., K. J. Berg, S. Ragupathy, M. Palanisamy, K. Sambandan, and S. G. Newmaster. 2011. Local knowledge and conservation of seagrasses in the Tamil Nadu State of India. Journal of Ethnobiology and Ethnomedicine 7(37). DOI: 10.1186/ 1746-4269-7-37.

[12] Short, F., T. Carruthers, W. Dennison, and M. Waycott. 2007. Global distribution and diversity diagram: A bioregional model. Journal of Experimental Marine Biology and Ecology 350, 3-20.
[13] Effendi, H. 2003. Telaah kualitas air, bagi pengelolaan sumber daya dan lingkungan perairan.Kanisius Publisher. Jakarta.

[14] Riniatsih, I., and E. W. Kushartono. 2009. Basic substrate and oceanographic parameters as determinants of the existence of gastropods and bivalves in Sluke Beach, Rembang Regency, Sluke Beach, Rembang Regency. Journal of Marine Sciences 14(1), 50-59.

[15] Hutabarat, S., and S. M. Evans. 1985. Introduction to Oceanography. University of Indonesia Press. Jakarta.

[16] Mason, C. F. 1998. Biology of freshwater pollution, $2^{\text {nd }} \mathrm{Ed}$. Longman Scientific and Technical. New York.

[17] Erftemeijer, P. I. A., and J. J. Meddelburg. 1993. Sediment-nutrient Interactions in tropical seagrass beds: a comparison between a terrigenous and a carbonate sedimentary environment in South Sulawesi (Indonesia). Marine Ecology Progress Series 102, 187-198.

[18] Berwick, N. L. 1983. Guidelines for analysis of biophysical impacts to tropical coastal marine resources. The Bombay Natural History Society Centenary Conservation Seminar in Developing Countries-Problems And Prospects. Bombay. 6-10 December 1983.

[19] Nybakken, J. W. 1992. Marine Biology: An Ecological Approach. PT Gramedia. Jakarta.

[20] Wijayanti, H. 2007. Aquatic quality in Bandar Lampung City beach based on animal makrobenthos community. Master Thesis. Diponegoro University. Semarang. 